\title{
Motív transformácie ludskej figúry v arcinaratívoch ako rezíduum rituálov prechodu
}

\author{
Nikola Danišová \\ Oddelenie semiotických štúdií, Ústav literárnej a umeleckej komunikácie, Filozofická fakulta, Univerzita Konštantína Filozofa, \\ Štefánikova 67, 94974 Nitra, Slovenská republika
}

Do redakce doručeno 12. srpna 2019; k publikaci přijato 29. ř́ina 2019

\section{THE HUMAN FIGURE TRANSFORMATION MOTIF IN ARCINARATIVES AS A RESIDUAL OF TRANSITION RITUALS}

\begin{abstract}
In the present paper, there will be explored the fairytale-mythological motif of the transformation of fictional hero in connection with the mythological-religious thinking of man on a transcultural and trans-genre sample of ancient text (myths, magic classic fairy tales, epics, etc.). I tis prefered to focus on analogous relationship between transformation and initiation (Propp, Eliade, Campbell) ritual, specifically, process of individualization (Jung, Bettelheim, von France).
\end{abstract}

KEY WORDS thematology; existential semiotics; archnarratives; motif of transformation; initiation ceremony; interpretation

\begin{abstract}
ABSTRAKT V predloženom príspevku sa na transkultúrnej a transžánrovej vzorke starobylých textov (mýty, čarovné klasické rozprávky, eposy a pod.) pokúsime preskúmat rozprávkovo-mytologický motív transformácie fiktívneho hrdinu v súvislosti s mytologicko-náboženským myslením človeka. Prednostne sa pritom sústredíme na analogický vztah transformácie a iniciačného rituálu (Propp, Eliade, Campbell), resp. procesu individualizácie (Jung, Bettelheim, von France).
\end{abstract}

\section{KLÚČOVÉ SLOVÁ tematológia; existenciálna semiotika; arcinaratívy; motív transfigurácie; iniciačný rituál; interpretácia}

Štúdia vznikla v rámci projektu APVV-17-0026 Tematologická interpretácia, analýza a systematizácia arcinaratívov ako semiotických modelov životného sveta a existenciálnych stratégií.

Vzhladom $\mathrm{k}$ interdisciplinárnej povahe a tematologickému zameraniu proponovaného výskumu (motív transformácie/ iniciácie fiktívneho hrdinu), ktorý sme načrtli už v rámcových častiach príspevku (názov/titul, abstrakt), môžeme náš príspevok metodologicky ukotvit pod novovznikajúcu literárnovednú/umenovednú subdisciplínu arcitextuálna tematológia (M. Čechová, L. Plesník). Arcitextuálna tematológia sa zaoberá témou „ako výrazom/prejavom (mystéria) zakladajúcej skúsenostnej a nadindividuálnej, historicky i praxeologicky overenej múdrosti, ktorá podkladá a zároveň presahuje čisto individuálne kreácie“ (Čechová 2017, 280). ${ }^{1} \mathrm{~V}$ našom výsku-

1 Viac k pojmu arcitextuálna tematológia pozri: Čechová 2017, $278-282$. me chápeme pod témou v širšom zmysle transformačný motív, ktorý je osnovným príbehovým algoritmom objavujúcim sa v každom dnes známom civilizačno-kultúrnom okruhu, $\mathrm{v}$ užšom zmysle zase transformačný motív, ktorý je rezíduom spoločensky aj individuálne dôležitého iniciačného rituálu.

Vzhladom k stanovenému rozsahu príspevku tvorí našu materiálovú bázu len malá, avšak žánrovo i kultúrne bohatá reprezentatívna vzorka kanonických/kultúrotvorných prapríbehov, ktoré môžeme na základe metodologického zaradenia (arcitextuálna tematológia) predloženého príspevku terminologicky zastrešit pod pojmom arcinaratív/arcitext/arcipríbeh (Čechová - Plesník). Podla M. Čechovej arcinaratív/arcitext/ arcipríbeh „Zväčša nemá individuálne identifikovaného autora. Je v tomto zmysle kolektívne generovaným a korigovaným 
výtvorom (...) predstavuje príbeh či text, ktorý má z hladiska vývinu tej či onej kultúry (jej subsystému, areálu a pod.) osnovný, zakladajúci význam, je slohotvorný a podkladá určitý ideologický archetyp (...) môže ustanovujúco vyjadrovat' istý životný pocit (v zmysle Heideggerovej naladenosti), poňatie životného sveta a pobytu v ňom" (Čechová 2017, 278). Z čisto „technologického“ (intertextuálneho) hladiska, sa koncept arcinaratívu/arcitextu sémanticky čiastočne prekrýva s Genettovými termínmi architextu/architextuality či s Popovičovým termínom prototextu (Čechová 2017, 279-280).

\section{SUBSTANCIÁLNA/TRANSCENDENTNÁ PREMENA AKO PODSTATA MAGICKO-MYTOLOGICKÉHO MYSLENIA ČLOVEKA A SYMBOLICKÉHO VYJADRENIA ŽIVOTNÉHO/EXISTENČNÉHO CYKLU}

Transformácia/metamorfóza je proces zmeny určitých vlastností fenoménu/substancie do inej podoby. Transformačnému procesu podlieha všetko živé i neživé: ludská bytost', zviera, rastlina, prírodný úkaz, vec a pod. $V$ rámci nášho výskumu považujeme za vhodné rozlíšit ontogenetickú/fylogenetickú a substanciálnu/transcendentnú premenu.

Ontogenetická/fylogenetická premena primárne súvisí s biologicko-fyzikálnym vývojom rastlín a živočíchov, u človeka a zvierat zahŕňa tiež psychologicko-kognitívny vývin organizmu (napr. formovanie osobnosti, dospievanie) a je relevantná rovnako pre aktuálny i fikčný svet (podla Doleželovho pojmoslovia).

Substanciálna/transcendentná premena predstavuje transformačný proces, ktorého subjekt/agens dočasne alebo navždy stratí pôvodnú podobu, resp. doterajšiu fyzickú či duševnú/duchovnú identitu, a tým aj spoločenský status. Ide o univerzálne antropologický a naratívne fixovaný fenomén, ktorý sa objavuje od najstarších dôb ludského vývoja v každej spoločnosti a kultúre (od dávnovekej ludovej obradnosti a slovesnosti až po novodobé kultúrotvorné a obrazotvorné prejavy).

Substanciálna/transcendentná premena prvotne súvisí s magicko-mytologickým myslením človeka. Prednostne sa sprítomňuje vo fikčných svetoch (mýty, čarovné rozprávky, báje a pod.), kde postihuje fiktívnu postavu. V aktuálnom svete substanciálna/transcendentná premena zvyčajne nadväzuje na biologicko-fyzikálny a psychologicko-kognitívny vývoj ludskej bytosti, ktorý je oddávna zvýznamňovaný tzv. rituálmi prechodu (A. Gennep), predovšetkým rituálom iniciácie (Propp, Eliade, Campbell), resp. individualizácie (Jung, Bettelheim, von France).

Významný francúzsky antropológ a religionista A. van Gennep tvrdí, že rituály prechodu sprevádzali prechod (prerod) človeka $\mathrm{z}$ jedného spoločenského postavenia, alebo obdobia do druhého, spravidla kvalitatívne vyššieho: „Už jen to, že člověk žije, vyžaduje postupné přecházení z jedné zvláštní společnosti do druhé a od jednoho společenského postavení k druhému - takže se život člověka skládá ze sledu různých etap: narození, společenské dospívání, sňatek, otcovství, třídní postup, specializace zaměstnání a smrt, jejichž konce a začátky tvoří celky téhož rázu. A ke každému z těchto celků se vztahujú obřady, jejichž cíl je stále týž - nechat jedince přejít od jedné determinované situace $\mathrm{k}$ jiné, zrovna tak determinované (...) člověk i společnost nějak závisejí na př́írodě, na vesmíru, který podléhá rytmům, které se odrážejí i v lidském životě“ (Gennep 1996, 13). Ritualizovanie životného prechodu či prerodu (t.j. substanciálna/transcendentná premena ludskej bytosti), pomáhalo človeku lepšie prijat’ novonadobudnutú spoločenskú rolu a s ňou súvisiace novozískané práva i povinnosti. V súhlase s Gennepovým tvrdením Bettelheim upozorňuje, že $\mathrm{v}$ rámci antropologických aj psychoanalytických podobností „mýty a pohádky byly odvozeny od iniciačních rítů či jiných rites de passage (přechodových rituálů) nebo byly jejich symbolickým vyjádřením - jako např́klad obrazná smrt starého, nedostačujícího bytostného Já, které má být znovuzrozeno na vyšším stupni existence“ (Bettelheim 2000, 47).

Gennep klasifikuje prechodové rituály do troch skupín:

a) zlučovacie rituály (napr. svadba, narodenie),

b) odlučovacie rituály (napr. úmrtie, pohreb),

c) rituály pomedzia (napr. iniciácia, tehotenstvo).

Najstaršie archeologické nálezy, ktoré by mohli svedčit’ o vykonávaní prechodových rituálov (a teda aj o substanciálnej/ transcendentnej premene) pochádzajú z konca stredného paleolitu (približne 200000 - 50/40 000 p. n. 1.). V tomto období sa podla mnohých bádatelov (Eliade, Campbell, Pastoureau, Podborský) začalo u neandertálskeho človeka rozvíjat magicko-mytologické myslenie. Archeologických nálezov z obdobia paleolitu však nie je mnoho a ich význam často nie je celkom zrejmý. Preto rozdelujú bádatelov na dva tábory: jedni tvrdia, že nájdené artefakty sú dôkazom o schopnosti magicko-mytologického, resp. symbolického myslenia u neandertáskeho človeka, druhí túto hypotézu popierajú.

Hoci nie je možné spolahlivo uviest', kedy (a či vôbec) sa u neandertálskeho človeka rozvinula potreba rituálne zvýznamňovat' ontogenetické/fylogenetické procesy (premeny), na základe archeologických nálezísk sa môžeme domnievat', že jeho prvotná rituálna činnost' a s ňou späté magicko-mytologické predstavy, mohli súvisiet’ s reinkarnáciou a iniciáciou človeka, ale tiež s reinkarnáciou existenciálne dôležitého lovného zvierata.

Medzi najstaršie pamiatky, ktoré by mohli niest’ stopy rituálnej činnosti, patria približne 60000 rokov staré neandertálske hroby (pohorie Karmel v Izraeli, jaskyňa Šánidar v Iráne a pod.), v ktorých sa okrem kostier uložených v embryonálnej polohe (predstava o návrate do „lona matky“) našli aj fragmenty zvieracích kostí a skromné milodary (jedlo, pracovné nástroje, ozdoby a i.): „mrtví byli posypáni okrem, představujícím náhražku krve, a pohřbívali je ve skrčené poloze, takže sedící nebo většinou ležící mrtvé tělo mohlo spočívat na levém boku s více nebo méně přitaženýma nohama. Byla tím napodobena poloha člověka ve spánku, ze kterého se opět probudí - což někdy bylo zdůrazněno orientováním nebožtíka na východ, $\mathrm{k}$ východu slunce -, př́padně poloha plodu v mateřském těle. Stejně jako leží nezrozený plod 


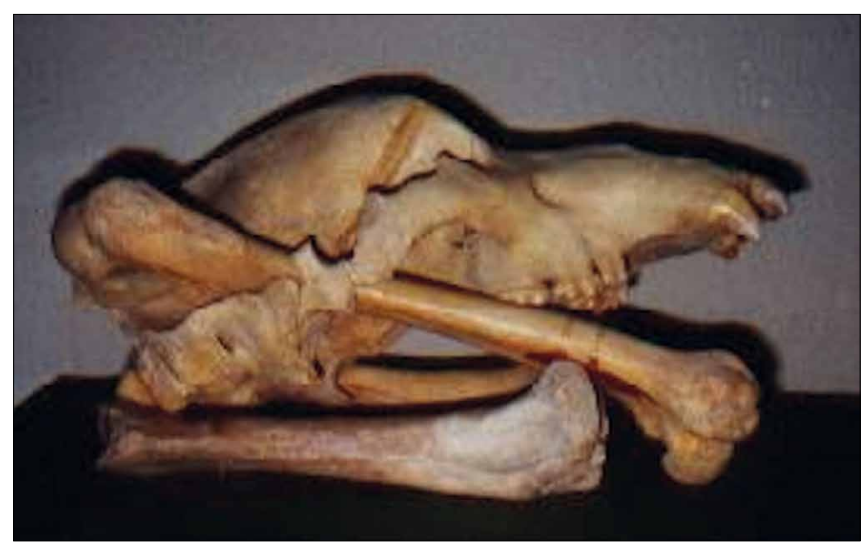

Obr. 1. Rituálne uložená lebka medveda jaskynného z archeologického náleziska v jaskyni Drachenloch (zdroj: http://antiquatedantiquarian.blogspot). com/2014/09/the-neandering-mind-burial-and-cult-of.html).

$\mathrm{v}$ břiše matky až do porodu, měl zemřelý ležet $\mathrm{v}$ lůně hrobu až do svého nového zrozeni“ (Bellinger 1998, 21-22). Podla amerického komparatívneho religionistu a mytológa J. Campbella takéto nálezy značia, že už neandertálsky človek mal určitú predstavu o záhrobnom živote, ak nie priamo o nesmrtelnosti (Campbell 2000, s. 13).

S predstavami o znovuzrodení lovného zvierata sa spája predovšetkým mysteriózny „kult medveda“ (obr. 1). Ide pravdepodobne o najstarší dochovaný zoomorfný kult. Jeho význam spočíval $v$ udobrení si uloveného zvierata, ktoré sa malo vd’aka úctivej pohrebnej ceremónii v novej podobe zrodit na tento svet. Pozostatky medvedieho kultu sa našli predovšetkým $\mathrm{v}$ európskych archeologických náleziskách (napr. v jaskyni Cueva Eiros v Španielsku, La Balme-á-Collomb vo Francúzsku, Drachenloch vo Švajčiarsku, Petershöle v Bavorsku, Drachenhötli v rakúskom Štajersku, Divje Babe v Slovinsku,). Náleziská odhalili kosti medveda jaskynného (dnes vyhynutý druh bol podla odhadov odborníkov omnoho mohutnejší, ako jeho dnešný príbuzný medved hnedý) starostlivo uložené $\mathrm{v}$ tažko dostupných útrobách jaskýň $\mathrm{v}$ špeciálnych kamenných výklenkoch, ktoré nápadne pripomínajú akúsi primitívnu svätyňu. Medvedia lebka tvorí centrum kamenného podstavca, z jej očnicových otvorov i sánky vyčnievajú tzv. dlhé kosti (stehenné a ramenné), čo vytvára dojem, akoby medved’ požieral sám seba (Pastoureau 2011, 33-36). Podla rumunského religionistu M. Eliadeho „, nejstarších tradicích loveckých národů - tradicích, které sahají do paleolitu - představovala kost zdroj života: právě do kosti byla soustředěna poslední podstata života, právě z nich každé zviře, ale i člověk znovu přicházeli na svět“2 (Eliade 1998, 144-145).

2 Predstava kosti ako podstaty/esencie života nie je neznáma ani agrárnym civilizáciám: „Vznešený, jenž jest mezi vámi, svázal mé kosti a pevně spojil mé údy (...) jako kdysi nasadil bílou korunu Atumovi, tak nasadil mou hlavu mně... "(egyptská Kniha mŕtvych CXXV:149); "A pohled' na tyto kosti, jak je zvedneme a potom je masem obalíme!" (Korán II:259); „A z rebra, ktoré vybral Adamovi, utvoril Pán, Boh, ženu a priviedol ju $k$ Adamovi“" (Svätá Biblia 2002, Gn 2:22); „Zaznel hlas a strhol sa lomoz: kosti sa zbližovali, každá kost' $k$ svojmu
Mnohí bádatelia však existenciu pravekého medvedieho kultu spochybňujú. Napríklad francúzsky historik A. Leroi-Gourhan je presvedčený, že uloženie zvieracích kostí je výsledkom náhodnej geologickej činnosti a činnosti samotných medvedov (Leroi-Gourhan 1981, 39). Nemecký antropológ F. E. Koby sa ku kultu medved vyjadril takto: „Vztahy paleolitických lidí a medvedů byly přeceňovány" (podla Pastoureau 2011, 34). Naopak prívrženci tejto hypotézy hladali analógiu k pravekému medvediemu kultu v zoomorfných kultoch mladších loveckých spoločenstiev, ktorých životná úroveň bola ešte donedávna velmi podobná životnej úrovni paleolitického človeka. Príslušníci týchto etník, existenčne závislí na love, prinášali obetiny zo zabitého zvierata tzv. Najvyššej bytosti, resp. Pánovi zvierat. ${ }^{3}$ Eliade konštatuje, že u Inuitov „obět spočívala právě ve vystavení lebky a dlouhých kostí zabitého zviŕete, tedy části, jichž si lovec nejvíce cenil (...) aby ho Pán zvířat mohl prríští rok vzkř́isit“" (Eliade 2008, 27). Podla Pastoureaua uctievali kult medveda, ktorého ústrednou myšlienkou bola viera $\mathrm{v}$ jeho reinkarnáciu, aj pôvodné sibírske národy ako sú Chantovia, Tunguzovia a Jakuti, škandinávski Sámovia a kanadskí grónski Inuiti (Pastoureau 2011, 34). Campbell sa zase domnieva, že historicky priamy pozostatok prastarého medvedieho kultu môžeme nájst v severnej časti Japonska, na ostrove Hokkaido a ostrove Sachalin (v súčasnosti patrí Rusku), kde žijú poslední príslušníci pôvodom kaukazského etnika Ainu (Campbell 1998, 42). Ainovia veria, že božským bytostiam sa život v ludskom svete zdá zaujímavejší. $Z$ tohto dôvodu sa bohovia obliekajú do zvieracích kožušín (premieňajú sa na zvieratá) a zo svojej božskej ríše zostupujú na ludské (profánne) územie. Ich neštastie však spočíva $\mathrm{v}$ tom, že zvieraciu kožušinu zo seba viac nedokážu sňat. Ainovia preto zvieratá, v domnienke, že ide o bohov, lovia a zvliekajú ich z kožušín, čím im zabezpečujú transcendentálny návrat do ich božského (sakrálneho) sveta. Rituálne zvliekanie kožušín ulovených zvierat-bohov

stavcu. Videl som, ako sa na ne uložili žily a mäso a na povrchu sa im natiahla koža“ (Svätá Biblia 2002, Ez, 37:7-8); germánsky mýtus o Thorových kúzelných kozloch: boh Thor usmrtí svojich kozlov, aby usporiadal hostinu. Na další deň vzkriesi zvieratá $\mathrm{z}$ hromady kostí, ktoré po nich zostali.

3 Pán zvierat, u niektorých loveckých spoločností Pani zvierat, je mýtická bytost’ prebývajúca hlboko v lese, alebo na dne mora. Rozhoduje o tom, či bude mat' lovec pri love štastie - ak áno a zviera bolo usmrtené/ulovené, vezme si jeho dušu spät k sebe. Ak však lovci nedokázali dlhšie ulovit žiadnu korist', boli presvedčení, že Pán/-i zvierat „uzavrel/-a" les či hladinu mora. Vtedy sa konali rôzne prosebné rituály a šaman podstupoval transcendentnú pút do inej ríše, aby bytost̉ primäl $\mathrm{k}$ navráteniu zveri do ludského sveta (Bellinger 1998, 27). Napríklad africkí Pygmejovia z kmeňa Bambuti stotožňovali svojho Pána zvierat - lesného ducha Tore, s pralesom, juhoamerickí Indiáni z kmeňa Tupí v Amazónii nazývali Pána zvierat Caapora, čo doslovne znamená „lesný obyvatel", ázijskí Semangovia z Malakky nazývali túto bytost' Karei. Trestala najmä tých lovcov, ktorí usmrtili tabuizovaného vtáka, alebo sa posmievali chromému či bezmocnému zvieratu. Inuiti nazývali svoju Pani zvierat, prebývajúcu v temných hlbinách mora, Sedna (ibid, 27-28) a pod. 


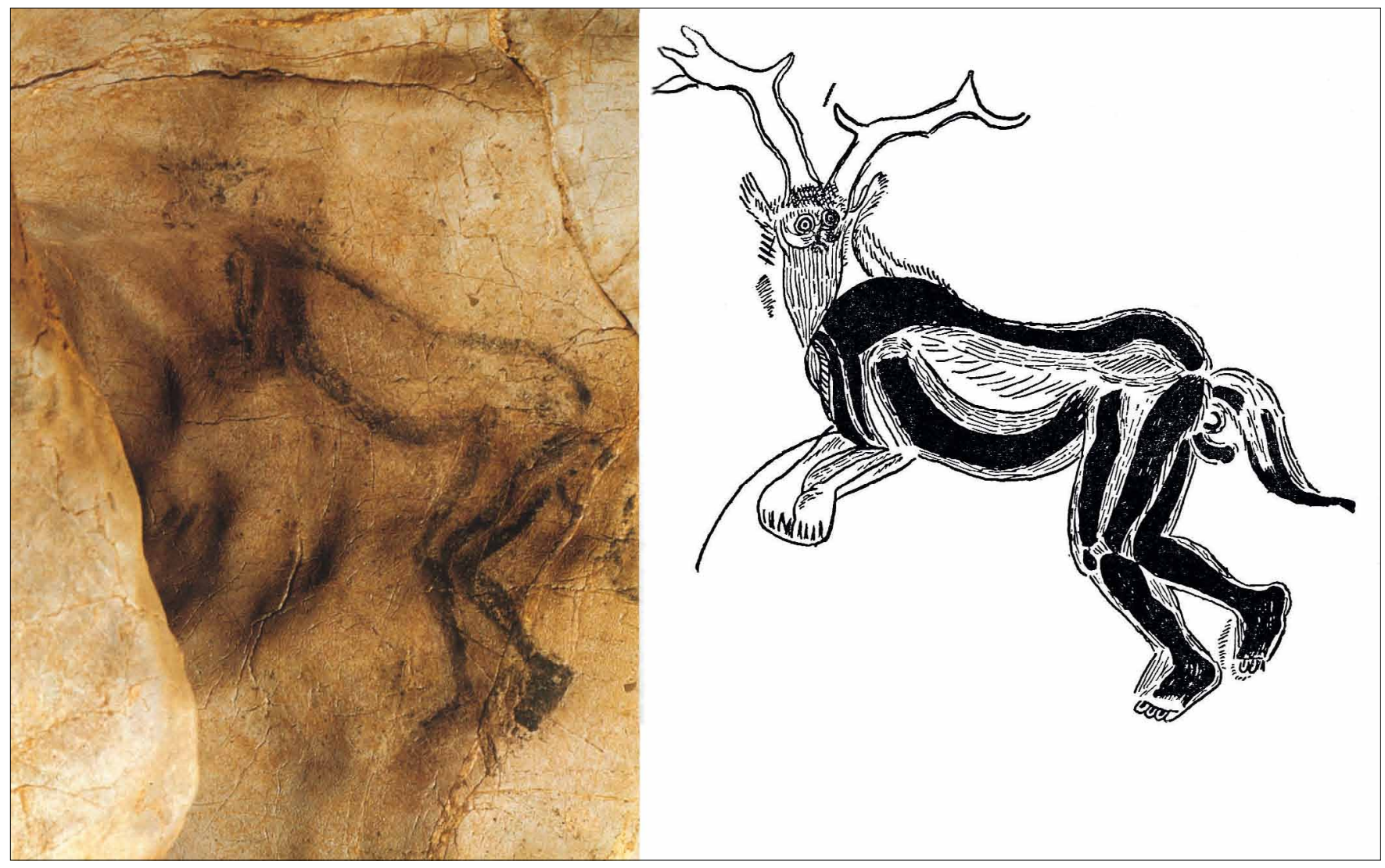

Obr. 2. Vyobrazenie tzv. čarodejníka v jaskyni Les Trois Fréres (zdroj: http://www.bradshawfoundation.com/index.php).

Ainovia vykonávajú aj v súčasnosti (Campbell 1998, s. 43). ${ }^{4}$ Hoci sú hypotézy o magicko-mytologickom uvažovaní neandertálskeho človeka sporné, archeologické nálezy datované do mladšieho paleolitu (t.j. od začiatku aurignacienu, približne okolo 40000 - 30000 p. n. 1.) už zretel’ne vykazujú rituálny zámer človeka rodu Homo sapiens. Ide predovšetkým o nálezy jaskynných rytín a malieb so zvieracou, resp. magicko-loveckou tematikou (napr. v jaskyniach Lascaux, Altamira, Les Trois Fréres, Ait Cenker, La Mouth), kostených i kamenných sošiek (Venuše ako symbol materstva a plodnosti). Jedna $\mathrm{z}$ najstarších, najvýznačnejších a najrozporuplnejších pamiatok, ktorá by mohla priamo ikonizovat' substanciálnu/transcendentnú figurálnu premenu, sa nachádza vo francúzskej jaskyni Les Trois Fréres a ide o nástennú malbu

4 Získali sme dojem, že kým v priebehu 20. storočia sa realizoval pomerne rozsiahly výskum archeologických nálezov medvedích „svätýń“ a diskusie okolo problematiky ne/pravosti tohto kultu boli velmi živé, $v$ súčasnosti sa táto kontroverzná téma odsunula na perifériu výskumnej činnosti akademickej obce. Väčšina nám známych vedeckých prác, zaoberajúcich sa tzv. medvedím kultom, pochádza z pola religionistiky, ktorá je jeho existencii naklonená, kým na poli antropologickom a historickom sú bádatelia skôr skeptický a tomuto fenoménu, najmä v súčasnosti, nevenujú náležitú pozornost'. Viac o medvedom kulte pozri Campbell 1998, 42-46; Eliade 2008, 27-30; Pastoureau 2011, 27-47. „čarodejníka“ (obr. 2). Sedemdesiatpät centimetrov vysoká, napoly zvieracia a napoly ludská postava, má jeleniu hlavu s mohutným parožím a vlčími ušami (tvárová čast' hlavy nápadne pripomína sovu), levie telo s konským chvostom a paže zakončené medvedími labami. Jeho ludskú podstatu prezrádzajú dolné končatiny, pohlavie a tanečný postoj. Okolo figúry čarodejníka sú vyobrazené lovné zvieratá, ako napr. bizóny, kone a jelene. Nie je celkom zrejmé, čo presne táto hybridná postava predstavuje: bud' ide o vyobrazenie šamana, ktorý sa počas obradu prezlieka do zvieracích kožušín (telesná premena), alebo o Pána zvierat, mýtickú božskú prabytost', ktorá zabezpečuje reinkarnáciu ulovených zvierat na pozemský svet (telesná i transcendentálna premena) (Eliade 2008, 32). K záhadnej malbe čarodejníka sa Campbell vyjadruje takto: „původní vstup [do jaskyne Les Trois Fréres - pozn. a.] vedl přes koryto dlouhé přibližně padesát metrů, jímž musel člověk lézt po čtyřech, což mohlo naznačovat motiv znovuzrození (...) jakmile se skrze koryto proplazí do jeskyně, spatří právě postavu čaroděje“ (Campbell 2000, 16).

Malba čarodejníka v jaskyni Les Trois Fréres nie je jediným vyobrazením ludsko-zvieracej figúry. Podla Eliadeho „v paleolitickém umění známe kolem 55 zobrazení lidí oblečených v kůži a někdy v taneční poloze“ (Eliade 2008, 32). Popri vyobrazení čarodejníka môžeme za jednu z najzaujímavejších jaskynných malieb (z vizuálneho i antropologického hladis- 


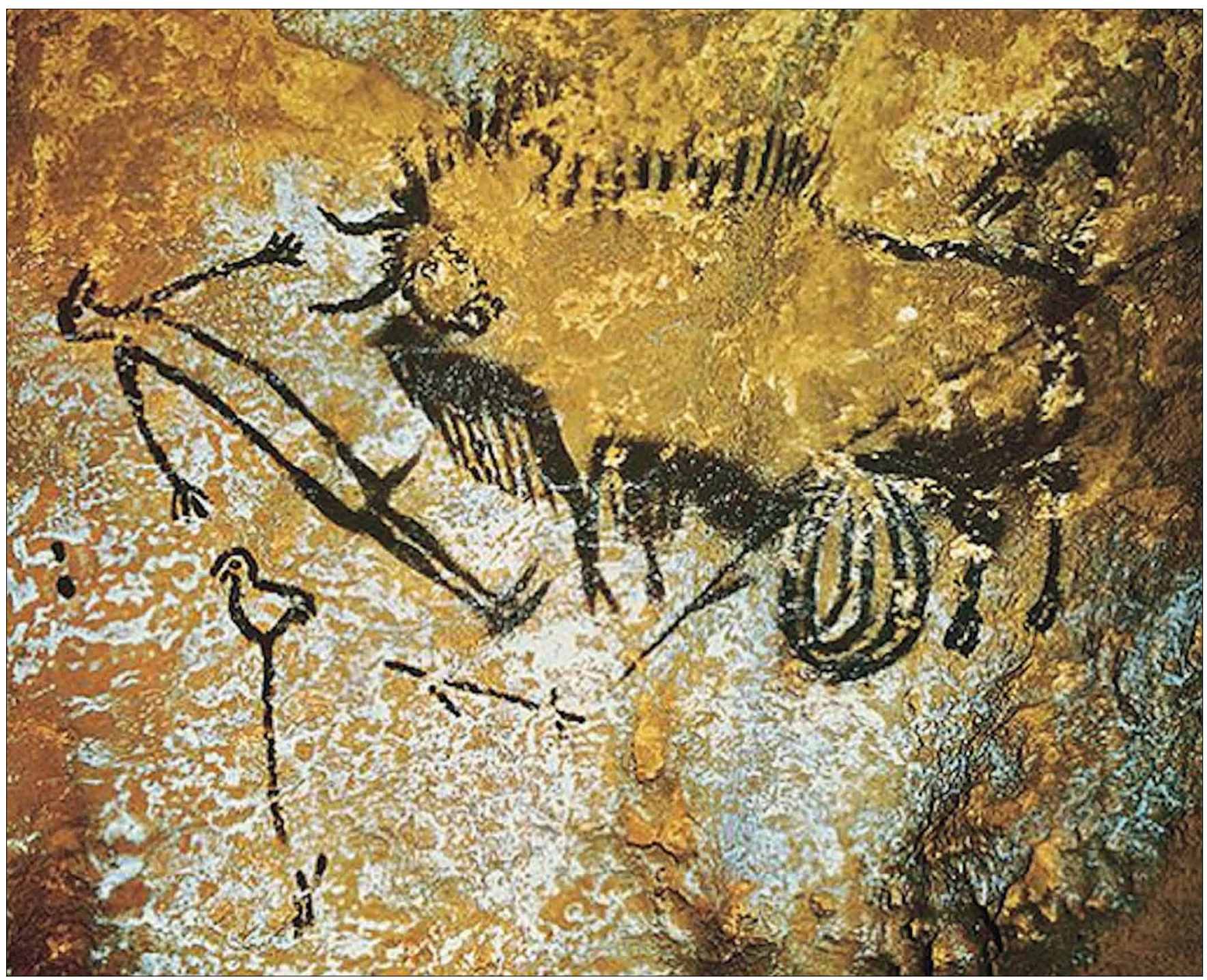

Obr. 3. Vyobrazenie postavy s vtáčou hlavou v jaskyni Lascaux (zdroj: http://www.bradshawfoundation.com/news/cave_art_paintings.php?id=Chauvet-s-scarcity-of-human-figures).

ka) považovat’ aj „ludskú postavu s vtáčou hlavou“ (obr. 3). Figúra je zobrazená so vztýčeným penisom namiereným priamo na zubra, ktorý je prepichnutý oštepom, resp. šípom. Táto mal'ba sa nachádza v jaskyni Lascaux. Podla R. Drösslera, špecialistu na astro-mytológiu, ide pravdepodobne o vyobrazenie šamana $v$ tranze, ktorého duša podstupuje domnelú cestu do záhrobia (sakrálneho sveta) k Pánovi zvierat, alebo k duchom ulovenej zveri, aby ich primäla k návratu do ludského (profánneho) sveta. Erektívny úd a zvláštny piktogram pripomínajúci vulvu (umiestnený pod bruchom zubra) naznačujú akt na-rodenia zvieracích duší do nových pozemských tiel (telesná i transcendentálna premena). Vták na bidle umiestnený vedla polo-ludskej a polo-vtáčej figúry, symbolizuje šamanovu dušu (Drössler 1980, 16).

V súčasnosti je už známe, že priestory jaskýň nemali obytnú funkciu, ale pravdepodobne predstavovali svätyňu transcendentného prechodu na onen (sakrálny) svet. Tajomné vyobrazenia zvierat a hybridných ludsko-zvieracích figúr slúžili budto na účely loveckej mágie (vrátane iniciácie mladých chlapcov, budúcich lovcov), alebo ako „náboženské ikony“, ktoré znázorňovali, resp. ulahčovali, šamanovi mystickú cestu do záhrobnej ríše duchov, či k Pánovi zvierat (Pastoureau 2011, 30-31). Priestor jaskyne (spolu s úžlabinou, vysokou horou, stromom, rebríkom/mostom atd'. $)^{5}$ je v mytologic-

5 Priechody do magických/záhrobných svetov sú v nábožensko-mytologických predstavách z netradičného, nebezpečného a tažko schodného materiálu, čo poukazuje na náročnost' cesty metafyzického poznania. Lezenie po rebríku, strome, vysokej hore, prechod po moste, cez rieku či cez nebezpečný priestor jaskyne apod., je častou súčastou iniciačnej skúšky mýtického/rozprávkového hrdinu, šamana i mŕtveho, ktorý fyzicky, alebo aj psychicky, putuje do sakrálnej, kozmickej sféry, resp. do priestoru, ktorý je v sémantickom kontraste k ludskému (profánnemu) svetu: „,vo sne videl [Jákob pozn. a.] rebrík postavený na zemi, ktorého vrchol sa dotýkal neba. Boži anjeli po ňom vystupovali a zostupovali. Nad ním stál Hospodin“ (Svätá Biblia, 2002, Gn, 28:12-13), hrdina Väinämöinen z fínskeho 
ko-náboženských predstavách šamanistických kultúr, ale aj starovekých civilizácií, vnímaný ako symbol axis mundi, tzv. stred/pupok sveta, ktorý predstavuje bránu do sakrálnej sféry (Eliade 2004, 37, 47). Z tohto dôvodu sú tmavé, vlhké jaskynné priestory (symbol Vel'kej Matky), kde sa stretáva božské a ludské, mystickým miestom šamanovho astrálneho/ mimotelového ${ }^{6}$ prechodu do záhrobného sveta nadprirodzených bytostí a iniciantovho zasvätenia, t.j. v oboch prípadoch transcendentného znovuzrodenia - premeny.

\section{ROZPRÁVKOVO-MYTOLOGICKÝ HRDINA AKO DESAKRALIZOVANÝ „OBRAZ“ ZASVÄCOVANÉHO INICIANTA/ŠAMANA}

Anglický antropológ Victor Witter Turner upozorňuje, že iniciant - „novic“ (Turner), sa počas obradu stáva tzv. liminárnou bytostou, ktorej nič nepatrí. Na začiatku rituálu je odlúčený od svojho známeho prostredia a prestrojený za netvora, príp. môže mat na sebe len kúsok látky, alebo byt úplne nahý na znamenie toho, že ako liminárna bytost̉ nemá žiadne postavenie, majetok, ani odznaky moci. Jeho doterajšia existencia je tak symbolicky usmrtená. Iniciant sa správa pokorne, bezvýhradne počúva svojho učitela a podstupuje rôzne skúšky ${ }^{7}$. Na konci obradu opúšta fázu liminarity a „Vchádza“

eposu Kalevala prechádza do záhrobia Tuonela po moste $\mathrm{z}$ mečov a nožov, po rebríku zo šípov sa na nebesá dostávajú hrdinovia z mýtov indiánskych etník Južnej a Severnej Ameriky, kaukazsko-iránske kmene zahrnujú do svojich mytologicko-náboženských predstáv most zvaný Činvat, ktorý je tenký ako čepel' britvy. Viac k tomu pozri Eliade, 2018, 408-412.

6 Viac pozri: M. Eliadeho: Šamanismus a archaické techniky extáze, 2017; Nelson, S. M.: Shamanism and the origin of states: Spirits, power and gender in East Asia, 2008; Balzer, M. M.: Shamanic worlds: Rituals and lore of Siberian and Central Asia. 1997.

7 Iniciant je počas obradu vel'mi často rituálne psychicky a fyzicky „mučený“. Silný existenciálny a extatický zážitok, ktorý novic prostredníctvom bolesti zažíva, rovnako ako presvedčenie, že takýmto spôsobom dosahuje spirituálne spojenie s bohmi, mení stav jeho vedomia. Toto duševné rozpoloženie by sme mohli pripodobnit k „vrcholovému zážitku“ (Maslow), ktorý je „iba dobrý a želaný, a nikdy nie je prežívaný ako zlý alebo neželaný (...) človek ho pocituje ako vnútorne potrebný a nevyhnutný (...) reaguje naň bázňou, úžasom, očarením, skromnostou a dokonca i úctou, velkým vnútorným štastím a zbožnostou“ (Maslow 2000, 101). Tento typ zážitku sa vyznačuje „hlbokou a prenikavou kvalitou, (...) ktorá sa paradoxne môže podobat na bolest', ktorá je často opisovaná ako sladká، “ (ibid., 106). Maslow uvádza, že ludia, ktorí zažili „peak experience“, t. j. vrcholový zážitok, často pripodobňovali zakúsený stav $\mathrm{k}$ umieraniu, avšak výsostne v pozitívnych aspektoch (ibid., 106). Napr. hinduistickí brahmani podstupujú počas iniciácie pomyselnú smrt', aby mohli prejst' do „dimenzie bytia“. Symbolická smrt pre nich znamená zničenie a opustenie doterajšieho profánneho sveta i života. Novic za sebou zanecháva všetko, čo doteraz vlastnil, vrátane oblečenia a mena (Gennep, 1996, 101). Traumatickejší iniciačný rituál podstupujú Zuinovia (kmeň amerických Indiánov). Chlapci sú počas rituálu niekolko dní v izolácii, o hlade a pod vplyvom psy- do nového stavu bytia: získava majetok, spoločenský status, s ním spojené odznaky moci a takto znovu-zrodený (telesne i transcendentálne premenený) sa vracia naspät do svojej komunity (Turner 2004, 96).

Proces novicovho rituálneho zasvätenia, ktorého podstatou nie je len ontogenetická/fylologická a sociálna premena (napr. z chlapca sa stáva muž), ale aj substanciálna/ transcendentná premena jeho vedomia, nápadne pripomína "cestu hrdinu“ (Campbell) v rozprávkovo-mytologických čarovných sujetoch. Podla českej literárnej teoretičky D. Hodrovej predstavuje iniciácia $\mathrm{v}$ najvšeobecnejšom zmysle slova oslobodenie ducha uväzneného v hmote (tele), vnútornú očistu, vzkriesenie, návrat $\mathrm{k}$ prapôvodnej dokonalosti, zázrak transsubstanciácie a spojenie s Bohom, od čoho sa priamo odvíja aj latinský význam slova „initium“ - počiatok, vchod, zasvätenie, mystérium (Hodrová 2014, 13).

Vo funkčno-typologickej koncepcii fikčných postáv ruského folkloristu Vladimíra Proppa, ktorý sa intenzívne zaoberal výskumom ruskej ludovej čarovnej rozprávky, je iniciantom postava fiktívneho hrdinu. Jeho osud nápadne zodpovedá Turnerovnu poňatiu iniciačnej skúšky: hrdina $\mathrm{v}$ expozí-

choaktívnych látok, čo v nich vyvoláva halucinácie, precitlivenost’ na vonkajšie podnety (ilúzia prechodu do iného sveta, kvalitatívna zmena vnímania) a celkovú dezorientáciu. Iniciátori obradu sa obliekajú do strašidelných masiek (predstavujú bytosti z iných svetov, napr. bohov, démonov, duchov) a oslabených iniciantov zbičujú. Nakoniec „strašidlá“ zhodia masky a roly sa vymenia: inicianti bičujú odmaskovaných mužov. Po tomto rituáli sa mladíci zaradia naspät do spoločnosti a získavajú status muža: môžu si založit rodiny a postavit' obydlie. Vzájomné bičovanie má údajne upevnit’ vzt’ahy medzi generáciami a zároveň poskytnút iniciantom skúsenost', že „nič nie je také strašné, ako sa zdá" (maskovaní netvori sú v skutočnosti starejší z osady) (ibid., 78-79). Podobné trýznivé obrady praktizujú aj dalšie kmene severoamerických Indiánov. Počas rituálu sauny (sweat lodge) „snáší skupina mužů utrpení vysoké teploty a šlehá se větvemi, tančí a zpívá" (Eliade - Culianu 2001, 219). Pri iniciačných rituáloch, ktoré sú spojené s mučením a sebapoškodzovaním, je obzvlášt dôležité bičovanie. Bičovaním sa iniciant „přijímá do totemického klanu, do rodiny nebo do světa mrtvých. Je třeba poznamenat, že bičování nebo rány jsou (...) materiálním rituálem odluky od dřívějšího světa“ (Gennep 1996, 160). Okrem bičovania plní takúto funkciu aj mrzačenie iniciantovho tela, ktoré označuje jeho nový spoločenský status. Ide napr. o židovskú obriezku, obrezávanie ženských pohlavných orgánov $\mathrm{v}$ moslimských krajinách, vybíjanie zubov alebo odrezávanie ušných lalôčkov v niektorých afrických kmeňoch či jazvové tetovanie u juhoamerických indiánskych kmeňov. „Obřady dospělosti se také mohou týkat pouze dospívajících dívek (...) obvykle spojované s menstruací. Názor, že menstruující žena je nečistá, je velmi rozšířený a v několika zeměpisných oblastech se všechny takové názory soustředily k první menstruaci“" (Benedictová 1999, 34). Napr. Indiáni v Britskej Kolumbii odvádzajú dospievajúce dievčatá na štyri roky daleko do hôr, kde žijú úplne osamote. Tento „pobyt“ sa nazýva „pochovanie zaživa“. Iniciatky počas neho nosia na hlavách velkú pokrývku z kože zvierata, ktorá im zakrýva tvár aj hrud’ a cez chrbát siaha až k zemi. Paže i nohy si dievčatá obväzujú pásmi šliach, aby ich chránili pred zlými duchmi. Po prekonaní tohto náročného, trýznivého obdobia dievča zhadzuje škaredý zvierací kostým, a ako dospelá/zrelá žena sa vracia naspät do komunity (ibid., 35). 
cii narácie pocituje určitý nedostatok (napr. smrt', únos či prekliatie blízkej osoby, túžba po dobrodružstve, strata majetku/vzácneho predmetu, nedostatok úcty okolia, hroziace nebezpečenstvo), a preto opúšta svoj domov. Až po odlúčení sa od známeho prostredia dokáže sužujúci nedostatok odstránit. Hrdina počas svojej cesty stretáva rôzne nadprirodzené postavy (baba Jaga, čarovné zvieratá, kúzelní majstri a i.) - v Turnerovom poňatí „učitelov", ktorí mu dávajú rôzne úlohy, rady, ohrozujú ho (často aj usmrcujú), alebo mu, naopak, pomáhajú. Hrdina, resp. rozprávkovo-mytologický „adept iniciácie“ (Hodrová), stojí počas svojich dobrodružstiev na počiatku/prahu ezoterického priestoru (vo fikčnom svete arcinaratívov ide napr. o začarovaný zámok či chalúpku, tajomnú záhradu, temný les, hlbokú jaskyňu či priepast'/úžlabinu, alebo vysokú horu, kde prebývajú nadprirodzené entity) a následne doň vstupuje, aby spoznal tajomstvá života a smrti (Hodrová 2014, 13). Hrdina, odkázaný sám na seba, testuje mimo bezpečia domova svoje hranice a možnosti, obohacuje sa o skúsenosti i ponaučenia, ktoré formujú jeho osobnost. V závere príbehu, rovnako ako iniciant $\mathrm{v}$ záverečnej fáze zasväcujúceho obradu, získava majetok, spoločenské postavenie, žení sa a často dosahuje „vylepšenie“ aj na personálnej úrovni svojej existencie (získava múdroste, sebapoznanie, osvojí si spoločensky ušlachtilé vlastnosti ako skromnost', láskavost̉ apod.), čím sa dovršuje jeho rozprávkovo-mytologická iniciácia.

Podla Proppa sa v čarovných rozprávkach proces zasväcovania - „cyklus iniciácie“, úzko spája so skúsenostou posmrtného života - „cyklus predstáv o smrti“. Nie je preto možné spolahlivo uviest', v ktorej časti rozprávkovo-mytologickej narácie sa nachádza hranica určujúca koniec jedného cyklu a začiatok druhého. Celý obrad iniciácie sa zároveň vníma ako pobyt v krajine smrti, ktorá je metaforou pre svet čarovných bytostí a naopak, s mŕtvym sa deje všetko to, čo preživa zasväcovaný (napr. získanie pomocníka, darcu, alebo stret $\mathrm{s}$ bytostou, ktorá chce hrdinu pohltit - metaforické vyjadrenie znovu-zrodenia/ob-rodenia) (Propp 1999, 169). Tak či onak, oba cykly sú podla Proppa stavebnými prvkami narácie čarovných príbehov a dohromady tvoria takmer celú ich kompozíciu (ibid., 169). Tento fakt je pri skúmaní našej problematiky, $v$ rámci ktorej chceme nazerat na rozprávkovo-mytologického hrdinu ako na desakralizovaný obraz inicianta/šamana, či zomrelého, určujúci, pretože výsledkom hrdinovho fyzického putovania do záhrobia, resp. jeho iniciačnej skúšky, je vždy istá forma substanciálnej/ transcendentnej premeny. Tá hrdinu zasahuje bud' na úrovni fyzickej (napr. získanie nového a krajšieho tela: severoamerický indiánsky príbeh Čarodejnica, čo vedela menit tváre, tibetský príbeh Dvaja bratia), duševnej (napr. získanie múdrosti a polepšenie charakteru: čínsky príbeh Starožitné zrkadlo, grimmovská rozprávka Král Drozdia brada), alebo sociálnej (napr. získanie majetku, královského titulu, božského statusu: slovenská rozprávka $O$ Hladošovi, grécky mýtus Eros a Psyché). Hrdinova substanciálna/transcendentná premena často prebieha na viacerých úrovniach jeho bytia súbežne.

\section{FIGURÁLNA TRANSFORMÁCIA V ARCINARATÍ- VOCH AKO REZÍDUUM RITUÁLOV PRECHODU - INTERPRETAČNÝ, INTERSEMIOTICKÝ A ANALYTICKÝ PRIENIK DO VYBRANEJ VZORKY ARCITEXTOV}

Demonštrujme našu hypotézu o hrdinovej transformácii v arcinaratívoch, ktorá môže do istej miery predstavovat pradávny pozostatok rituálov prechodu a ich modifikovaný, desakralizovaný obraz, na niekolkých arcitextoch z našej materiálovej vzorky. Ako vzorové interpretačné texty sme selektívne vybrali najstaršie písomne dochované kultúrotvorné arcinaratívy. Chronologicky ide o sumersko-babylónsky Epos o Gilgamešo$v i$, egyptskú čarovnú rozprávku $O$ dvoch bratoch a helénsko-rímsky román Premeny, čiže Zlatý somár. Pristúpme v nasledujúcom výklade $\mathrm{k}$ interpretácii jednotlivých arcitextov.

Najstaršie fragmenty sumersko-babylónskeho Eposu o Gilgamešovi, nájdené na hlinených tabul'kách, sa datujú až do 20. storočia p. n. 1 . Je však pravdepodobné, že príbeh sa medzi lud’mi šíril ústne už omnoho skôr a umelecký prednes niektorých jeho častí (napr. Gilgamešov a Enkiduov boj s netvorom Chuvavom v Cédrovom lese, zabitie nebeského býka bohyne Ištar, či Gilgamešove putovanie do záhrobnej ríše Dilmun za nesmrtelným Utanapištimom) bol významnou súčastou rôznych obradov (Zamarovský 1975, 71).

Za najdôležitejšiu čast' tohto epického diela považujeme, z hladiska našej výskumnej problematiky, práve sujetovo-motivické epizódy zachytávajúce Gilgamešovu cestu do záhrobia Dilmun, t.j. druhú polovicu dejovej línie eposu. Podnetom pre Gilgamešovu pút je smrt' milovaného druha Enkidua: uruckého krála, odvážneho a neporazitelného hérosa, sa zákerne zmocní existenciálny strach z vlastnej mortality a obsedantná túžba po nesmrtel’nosti. Vydáva sa preto na náročnú pút do ríše mŕtvych za tajomným Utanapištimom - jediným smrtelníkom, ktorého bohovia obdarili „večným životom“. Naratívna arcimotivéma hrdinovho dramatického a život ohrozujúceho putovania do záhrobného sveta, znázorňuje v metaforickom kóde príslušného textu magicko-mytologické predstavy o náročnej a často nebezpečnej púti nebožtíka (resp. jeho duše) do záhrobné sveta. Gilgameš sa na svojej ceste stretáva s rôznymi nadprirodzenými božskými a démonickými postavami, ktoré sa ho snažia od púte do Dilmunu odradit a pripomínajú mu, že údelom človeka je viest’ svoj život k nevyhnutnej smrti. Jednou z týchto postáv je, napríklad, božská krčmárka Siduri. Upozorňuje Gilgameša, že kým sa snaží získat nesmrtelnost', život samotný mu uniká: „,Život, který hledáš, nenajdeš, ř̀ kla mu Siduri. ,Když velcí bohové stvořili lidstvo, určili lidstvu los smrti, věčnost si nechali pro sebe ve svých rukou. Jiný však život hledej, hrdino Gilgameši, poslechni mou radu! Hled' si svého blaha, naplň si žaludek, poř́ádně se napij, ve dne v noci se vesel! Každý den oslavuj svátek, hoduj (...)tancuj a zpívej, věnuj se radovánkám (...) Tak si počínají lidé, takový život je určen lidstvu! “ (Zamarovský 1975, 33). Gilgameš však nepočúva Sidurine múdre slová a putuje d’alej. Napokon sa vdaka prievozníkovi 
dostáva cez rieku priamo do podsvetia, kde mu Utanapištim dáva náročnú skúšku: musí bdiet’ sedem dní a sedem nocí. Ak uspeje, získa dar nesmrtel’nosti. Gilgameš, vyčerpaní z dlhej púte do záhrobia, zaspí hlbokým spánkom, tak ako človek, ktorý je „unavený“ zo svojej púte životom a umiera. Hlboký spánok znamená v metaforickom kóde starobylých príbehov smrt' (Lurker 1999, 242). Hoci Gilgameš v tejto v skúške neobstojí, stále sa nedokáže zmierit so svojou smrtelnostou a podlieha zúfalstvu. Preto mu Utanapištim prezradí, že na dne mora rastie zázračná rastlina - po jej požití sa stane nesmrtel'ným. Gilgameš vzácnu rastlinu získa. Opät si chce po náročnej úlohe odpočinút a práve to sa mu opät stáva osudným: počas spánku mu rastlinu „večného života“ zožerie had. Ďalší neúspech napokon zdrveného Gilgameša vedie $\mathrm{k}$ precitnutiu a k hlbokému pochopeniu podstaty svojej existencie: neodvratným údelom človeka je umriet', eufemisticky povedané „zaspat' naveky“. Po intenzívnom duchovnom prerode sa vracia do rodného mesta Uruk, kde po zbytok života vládne ako múdry a spravodlivý král.

Ďalším prastarým textom z našej výskumnej vzorky, ktorý tematizuje motív substanciálnej/transcendentnej premeny, je staroegyptský príbeh $O$ dvoch bratoch nazývaný aj $A n p u$ a Bata. Český literárny vedec K. Horálek považuje rozprávku o dvoch bratoch za najstaršiu úplne zachovanú čarovnú rozprávku svetovej slovesnosti. Rukopis, na ktorom sa rozprávka zachovala, pochádza z 13. storočia p. n. l. (Horálek 1979, 174). Podla Horáleka sujet rozprávky vznikol spojením troch samostatných a starších poviedok do jedného „kompaktného“ dejového celku (podobne ako Epos o Gilgamešovi). Tiež dodáva, že rozprávka vykazuje značnú príbuznost' s novodobými rozprávkami. Ide, napríklad, o motív hovoriaceho zvierata-pomocníka, magického úteku, alebo niekol'konásobných čarovných premien hrdinovho tela (Horálek 1979, 178), ktoré v metaforickom kóde čarovného sujetu zobrazujú jeho transcendentnú/iniciačnú cestu znovu-zrodenia.

Staroegyptská rozprávka Anpu a Bata je pomerne neznáma, navyše má komplikovanú dejovú linku, preto uvedieme jej sujetovú osnovu:

Anpuova manželka falošne obviní svojho švagra Bata $\mathrm{z}$ toho, že ju chcel znásilnit. Rozhnevaný Anpu sa preto rozhodne mladšieho brata zabit'. Bata však zistí bratove úmysly včas (varuje ho kúzelná hovoriaca krava) a stihne ujst’ z jeho domu. Anpu v záchvate zúrivosti prenasleduje nevinného Bata. Ked' ho doženie, boh Fra Harmakhuti (slnko Horus) vykúzli medzi bratmi ako nezdolatelnú prekážku rieku s krokodílmi. Vtedy Bata rozpovie Anpuovi, čo sa skutočne prihodilo a očistí svoje meno - odreže si ruku, ktorou prisahal svoju nevinu a hodí ju krokodílom. Pred vstupom do Údolia cédru (mystický názov záhrobného sveta) si vyreže z tela srdce a uloží ho na najvyšší kvet cédrového stromu. Potom dáva bratovi tieto inštrukcie: ked'sa mu skalí pivo, znamená to, že niekto zotal cédrový strom, na ktorom leží Bataovo srdce a on umrel. Vtedy mu musí íst' Anpu na pomoc. Bata sa v miery rozlúči s Anpuom a odchádza do záhrobia. V záhrobí stvoria bohovia pre Bata ženu, no predpovedajú jej krutú smrt'. Bata jej preto zakazuje vychádzat z domu. Žena však zákaz poruší a odíde k ne- dalekému cédru, na ktorom leží Bataovo srdce. Zrazu k nej príde prúd rieky a chce ju uniest'. Žene sa podarí ujst' naspät' do domu, no rieka odnesie prameň jej vlasov do sveta živých. Vlasy nájde faraón a zamiluje sa do ich majitelky. Posiela lukostrelcov do Údolia cédru a Bataovu ženu unesie. Žena, polichotená láskou samotného faraóna, zradí Bata a nechá zotat strom, na ktorom leží jeho srdce. Bata umiera a na pomoc mu prichádza Anpu, ktorému sa podla predpovede skalilo pivo. Nájde mŕtveho brata a jeho srdce hodí do vody. Bata ožije a vzápätí sa mení na „Vel'kého býka“. V tejto podobe inkognito prichádza do faraónovho paláca, kde ho uctievajú. Zákerná žena ho spozná i v zvieracej podobe a vystrašená Bataovým zmŕtvychvstaním presvedčí faraóna, aby býka rituálne zabil. Zo zvieracej krvi však vyrastú dva vavrínové kríky, do ktorých sa inkarnuje Bataova duša. Žena prikáže vavríny zotat', ale jedna trieska jej vletí do úst - z nej počne diet’a. Syn, ktorý sa žene narodí, je d’alšou inkarnáciou Bata. Ked' chlapec vyrastie a stane sa podla dedičského práva faraónom, verejne rozpovie príbeh o zradnom konaní svojej ženy-matky a nechá ju popravit'. Po prekonaní všetkých prekážok napokon sám vládne ako faraón.

Motív Bataových transformácií prvotne súvisí s vierou v reinkarnáciu mŕtveho a s iniciačným procesom. Bataov odchod do Údolia cédru, kde istý čas žije s bohmi, predstavuje v metaforickom kóde transcendentný prechod do záhrobnej ríše nadprirodzena. Bataova smrt', ktorá nastane po zničení cédrového stromu a jeho následné zmŕtvychvstanie, potom predstavujú transcendentný návrat zo záhrobnej ríše do sveta živých. V sujetovej osnove môžeme nájst' aj niekol'ko somatických premien, konkrétne premenu na „Vel'kého býka“ a vavrínové kríky, ktoré predstavujú dalšie formy Bataovho bytia na „inkarnačnej ceste“. Tá je ukončená v závere príbehu, kedy nastáva Batauovo plnohodnotné znovuzrodenie $\mathrm{z}$ lona ženy-matky do ludského tela.

Za mimoriadne dôležitý text $\mathrm{z}$ našej výskumnej vzorky, ktorý zobrazuje protagonistovu substaciálnu/transcendentnú premenu, pokladáme rímsky román Premeny čiže Zlatý so$m a ́ r^{8} \mathrm{z}$ 2. stor. n. l. Apuleiov román je všeobecne považovaný za prvý iniciačný a jediný celkom dochovaný rímsky román. Jeho dejová línia je tvorená na princípe rámcujúceho rozprávania. Ťažiskovou, rámcujúcou, témou románu je vnútorná (personálna) transformácia bohémskeho Lukiana, ktorý v expozícii narácie prichádza do tajomnej Tesálie, aby sa naučil kúzlit. Lukianos žije búrlivým, pôžitkárskym životom a neustále sa ženie za dobrodružstvami, ktoré sú plné nadprirodzených bytostí, mystiky a čarodejníckeho umenia. Jedného dňa však doplatí na svoju lahkovážnu povahu a omylom sám seba prečarí na osla. V oslej koži Lukianos strastiplne putuje po svete a počúva najrôznejšie (aj čarovné) príbehy, ktoré prispievajú $\mathrm{k}$ jeho životnému ponaučeniu a duchovnému precitnutiu. Lukianova životná iniciačná premena je dovŕšená v závere príbehu, kedy sa vd’aka bohyni Izis oslobodí z oslej

8 Apuleius napísal svoj román na základe predlohy Lukianos alebo osol (približne 2. stor. n. 1.) od rímskeho satirika a rečníka Lukiana zo Samosaty. 
podoby, stáva sa jej kňazom a celkom zanecháva bohémsky život.

Naproti prvým dvom textom z našej výskumnej vzorky, rímsky román prvotne zobrazuje hrdinov iniciačný prerod, než jeho metaforickú cestu do záhrobia a pobyt v ňom. Autor románu tiež dej zasadzuje viac do profánneho/svetského priestoru, kým v prvým dvoch textoch sa hrdina viac pohybuje $\mathrm{v}$ sémantickom poli sakrálneho priestoru, t. j. v čarovnom, resp. záhrobnom svete.

\section{ZÁVER}

Fenomén premeny (resp. jeho ikonizácia) je naratívnym a antropologicko-náboženským javom, ktorý sa objavuje od najstarších dôb ludského vývoja v každom dnes známom kultúrno-civilizačnom okruhu. Akákolvek transformácia zobrazovaná vo fikčných svetoch ludových príbehov (či už ide o personálnu/transcendentnú, alebo somatickú čarovnú premenu) je vo svojej podstate zmenou identity subjektu/agensa a jeho prestupom $\mathrm{z}$ jedného stavu bytia do druhého, spravidla kvalitatívne lepšieho. Vo svojej prapodstate preto metamorfný motív zobrazujúci sa v kultúrne i žánrovo rôznorodých arcitextoch, nadväzuje na spoločensky aj individuálne dôležitý iniciačný, resp. individuačný proces.

\section{PRAMENE}

Apuleius (1960): Zlatý osel. Praha: Státní nakladatelství krásné literatury a umění.

Elaguin, Alexis (1931): Nejkrásnější pohádky východu. Praha: Šolc a Šimáček. Grimm, Jacob - Grimm, Wilhelm (1988): Pohádky. Praha: Odeon.

Hrbek, Ivan (2000): Korán. Praha: Academia.

Lenčo, Ján (1976): Čarovný kameň: rozprávky z Tibetu. Košice: Východoslovenské vydavatel'stvo.

Lexa, František (1994): Egyptská kniha mrtvých. Praha: Globus.

Němcová, Božena (1988): Strieborná kniha rozprávok. Bratislava: Pravda.

Príbus, Michal (1970): Manituov dar : indiánske rozprávky. Bratislava: Mladé letá.

Roháček, Jozef (2012): Svätá Biblia. Banská Bystrica: Slovenská biblická spoločnost'.

Gašparíková, Elena (1988): Z rozprávky do rozprávky. Bratislava: Mladé letá. Zamarovský, Vojtech (1975): Epos o Gilgamešovi. Bratislava: Mladé letá.

\section{LITERATÚRA}

Balabán, Milan - Tydlitátová, Veronika (2002): Gilgameš. Mýtické drama o hledání věčného života. Praha: Vyšehrad.

Bellinger, Gerhard (1998): Sexualita v náboženstvích světa. Praha: Academia.
Bettelheim, Bruno (2000): Za tajemstvím pohádek. Proč a jak je číst v dnešní době. Praha: Lidové noviny.

Campbell, Joseph (1998): Mýty. Legendy dávných věků v našem denním životě. Praha: Pragma.

Campbell, Joseph (2000): Proměny mýtu v čase. Praha: Portál.

Campbell, Joseph (2000): Tisíc tváŕi hrdiny. Praha: Portál.

Čechová, Mariana (2017): Arcinaratív/arcitext - tematický algoritmus - arcitextuálna tematológia. Litikon, 2(1), 278-282.

Čechová, Mariana (2015): Archetyp figurálnej ambiguity. Slavica Nitriensia: časopis pre výskum slovanských filológií, 4(2), 52-62.

Danišová, Nikola - Čechová, Mariana (2019): Prolegomena k pramotívu premeny. Verbum: Praha.

Doležel, Lubomír (2003): Heterocosmica. Fikce a možné světy. Praha: Karolinum.

Drössler, Rudolf (1980): Když hvězdy byly ještě bohy. Praha: Panorama.

Eliade, Mircea (2008): Dejiny náboženského myšlení. Od doby kamenné po eleusínská mystéria, 1. zv. Praha: Oikoymenh.

Eliade, Mircea (1998): Mýty, sny a mystériá. Praha: Oikoymenh,

Eliade, Mircea (2004): Obrazy a symboly. Brno: Computer Press.

Eliade, Mircea (2017): Šamanismus a archaické techniky extáze. Praha: Argo.

Eliade, Mircea - Culianu, Ioan Petru (2001): Slovník náboženství. Praha: Argo.

Gábor, Lubomír (2015): Formy, prejavy a mytologické aspekty hraníc v ludovej rozprávke. Slavica slovaca. 50(2), 116-131.

Gennep, Arnold van (1996): Přechodové rituály. Systematické studium rituálů. Praha: Lidové noviny.

Hodrová, Daniela (2014): Román zasvěcení. Praha: Malvern.

Horálek, Karel (1979): Folklór a svetová literatura. Praha: Academia.

Leroi-Gourhan, André (1981): Die Religionen der Vorgeschichte. Frankfurt am Main: Suhrkamp.

Lurker, Manfred (2005): Slovník symboli̊. Praha: Knižní klub.

Maslow, Abraham Harold (2000): Ku psychológii bytia. Modra: Persona.

Pastoureau, Michel (2011): Medvěd: př́iběh svrženého krále. Praha: Argo.

Propp, Vladimír Jakovlevič (1999): Morfologie pohádky a jiné studie. Jinočany: $\mathrm{H} \& \mathrm{H}$.

Radin, Paul (2005): Trickster. Mýtus o Šibalovi. Indiánsky mýtus v kontextu světových mytologií. Praha: Dobra.

Saunders, Nicholas (1996): Mytická síla zviřat. Praha: Knižní klub.

Turner, Victor (2004): Prủběh rituálu. Brno: Computer Press.

\section{AUTORKA}

Danišová, Nikola (1992, Lučenec), bakalárske štúdium absolvovala na Pedagogickej fakulte Univerzity Konštantína Filozofa v odbore výtvarné umenie - estetická výchova. Nasledujúce magisterské štúdium na Filozofickej fakulte Univerzity Konštantína Filozofa v odbore estetika (Ústav literárnej a umeleckej komunikácie). Doktorandské štúdium dokončila v roku 2019 na Filozofickej fakulte Univerzity Konštantína Filozofa (Oddelenie semiotických štúdií v Ústave literárnej a umeleckej komunikácie).

Kontakt: Mgr. Nikola Danišová, PhD.

email: nikol.danisova@gmail.com 